Table 4. Comparison of 1973 and 1986 adjustments

\begin{tabular}{cccc}
\hline & $\begin{array}{c}\text { change from } \\
1973 \\
\text { quantity }\end{array}$ & $\begin{array}{c}\text { uncertainties } \\
\text { recommended } \\
\text { value } \\
\text { (ppm) }\end{array}$ & \multicolumn{2}{c}{$\begin{array}{c}\text { recommended } \\
\text { values } \\
\text { (ppm) }\end{array}$} \\
\hline$\alpha^{-1}$ & -0.37 & 1973 & 1986 \\
$e$ & -7.4 & 2.9 & 0.30 \\
$h$ & -15.2 & 5.4 & 0.60 \\
$m_{\mathrm{e}}$ & -15.8 & 5.1 & 0.59 \\
$N_{\mathrm{A}}$ & +15.2 & 5.1 & 0.59 \\
$m_{\mathrm{p}} / m_{\mathrm{e}}$ & +0.64 & 0.38 & 0.020 \\
$F$ & +7.8 & 2.8 & 0.30 \\
$2 e / h$ & +7.8 & 2.6 & 0.30 \\
\hline
\end{tabular}

recommended value by $0.036 \pm 0.059$ $\mathrm{ppm}$. The WQED value of $K_{\mathrm{V}}$ differs from the recommended value by $0.01 \pm 1.03$ ppm. There is clearly no basis for any distinction between QED and WOED data.

By deleting the quantum Hall effect (QHE) data from the analysis one may investigate the validity of the theoretical relation $R_{\mathrm{H}}=h / e^{2}$. If the QHE data are deleted, the value of $\alpha^{-1}$ becomes 137.0359884(79); the difference from the recommended value is $-0.009 \pm$ $0.071 \mathrm{ppm}$. A value of $\alpha^{-1}$ from the Hall resistance data and the direct ohm determinations yields $137.0359943(127)$. This differs by only $0.043 \pm 0.085 \mathrm{ppm}$ from the value above. Thus, based on the presently available observational data, there is no evidence of any discrepancy in the QHE theory at the current levels of precision.

\section{REFERENCES}

1. Comptes Rendus des Séances de la $17^{\circ}$ CGPM (BIPM, Sèvres, France) 1983.

2. Hudson R.P. (editor), Metrologia 19 (1984) 163.

3. Deslattes R.D. et al., Phys. Rev. Lett. 33 (1974) 463 .

4. Seyfried P. et al., in Precision Measurement and Fundamental Constants II, eds. B.N. Taylor and W.D. Phillips, Natl. Bur. Stand. (US), Spec. Publ. 617 (U.S. Govt. Printing Office, Washington, DC) 1984, p. 313. 5. Van Dyck R.S. jr, Schwinberg P.B. and Dehmelt H.G., in Atomic Physics - 9, eds. R.S. van Dyck jr and E.N. Fortson (World Scientific Publishing Co., Singapore) p. 38. 6. Kinoshita T. and Sapirstein J., Op. Cit., p. 38.

7. Von Klitzing K., Dorda G. and Pepper M., Phys. Rev. Lett. 45 (1980) 494.

8. Imry Y., 'Klaus von Klitzing', Europhys. News, 16 (1985) 11/12.

9. Cohen E.R. and Taylor B.N., 'The 1986 Adjustment of the Fundamental Physical Constants', CODATA Bulletin No. 63 (International Council of Scientific Unions - Committee on Data for Science and Technology (CODATA), 51, Blvd de Montmorency, 75016 Paris, France) Nov. 1986.

10. "Recommended Consistent Values of the Fundamental Physical Constants, 1973", CODATA Bulletin No. 11 (ICSU, Paris) 1973.
11. Cohen E.R., Crowe K.M. and Du Mond J.W.M., Fundamental Constants of Physics (Interscience Publishers, New York) 1957. 12. Taylor B.N., Parker W.H. and Langenberg D.N., Rev. Mod. Phys. 41 (1969) 375; also published as The Fundamental Constants and Quantum Electrodynamics (Academic Press, New York).

13. Cohen E.R. and Taylor B.N., J. Phys. Chem. Ref. Data 2 (1973) 663.

14. Tuninskii V.S. and Kholin S.V., "Concerning changes in the methods for adjusting the physical constants", Internal Report, Mendeleyev Research Institute of Metrology (VNIIM), Leningrad; Metrologiya 8 (1975) 3 [in Russian].

15. Taylor B.N., "Numerical comparisons of several algorithms for treating inconsistent data in a least-squares adjustment of the fundamental constants", Natl. Bur. Stand. Report NBSIR 81-2426 (Jan. 1982).

16. Cohen E.R., "Extended' least squares", Report SCTR-76-1 (Rockwell International Science Center) Jan. 1976.

17. Cohen E.R., "An extended least-squares algorithm for treating inconsistent data", Report SCTR-78-11 (Rockwell International Science Center); see also ref. 4, p. 391.

18. Cohen E.R., in "Metrology and Fundamental Constants", Proceedings of the International School of Physics 'Enrico Fermi', Course LXVIII, eds. A. Ferro-Milone, P. Giacomo and S. Leschiutta (North Holland, Amsterdam) 1980, p. 581.

19. Taylor B.N., J. Res. Natl. Bur. Stand. 91 (1986) 299.

20. Taylor B.N., J. Res. Natl. Bur. Stand. 92 (1987) 55.

\title{
International Cooperation Strengthens European Optics
}

Two events, of considerable importance to the future of optical technology in Europe, marked the opening of the recent Fourth International Symposium on Optical and Optoelectronic Applied Science and Engineering, arranged by SPIE/ ANRT at the Hague in the Netherlands. These were the creation of a new association of West European Optical Societies called EUROPTICA, and the declaration of a Memorandum of Understanding (MOU) between EUROPTICA, EPS (European Physical Society) and SPIE - The International Society for Optical Engineering based in the USA.

In recent years, as the pace of developments in optical science and engineering has increased, and more European countries have formed their own Optical Societies, and also as a result of the now established trend, led by SPIE, for the organization of large multidisciplinary conferences, the need has arisen for the creation of a focal point through which future major international events could be channelled. As a start, the partners of the MOU have agreed to collaborate in the organization of one major meeting in Europe each year to be known as the International Conference on Optical Science and Engineering. This title has been chosen to reflect the interests of EPS in optical science, those of EUROPTICA in the industrial application of new developments in optics technology and the professional interests of optical engineers through their membership of SPIE. Plans are already well advanced for the first such meeting to be held from 19-23 September 1988 at the Hamburg Conference Centre (CCH). The second meeting will be in Paris from 24-28 April 1989 at the Palais des Congrès de la Porte Maillot.

This new partnership of non-profit bodies representing the interests of over 20,000 scientists, engineers and technologists in optics is expected to develop, in the course of time, to encompass other services to the optical community in the fields of education, exhibitions and publishing. The partnership will have the additional benefit of speeding up the transfer of technology into industry and helping to promote international trade. These activities will be managed by an appointed Joint Policy Committee (JPC) with the following representation:

EPS - European Physical

Society

H.A. Ferweda,

Universiteit Groningen

G. Thomas, EPS,

Secretary of JPC

H. Tiziani, Universität

Stuttgart, Institut für

Technische Optik,

Vice-chairman of JPC
EUROPTICA including Europtica Services

P. Bosec, ESSILOR

H. Walter, Director

Research and Development,

Rodenstock

P. Zaleski, Director, ANRT

For further information contact: Dr. L.R. Baker

Sira Ltd., South Hill, Chislehurst

Kent BR7 5EH, UK

Tel. : (1) 4672636

Telex: 896649

SPIE - The International Society of Optical Engineering

L.R. Baker, Technical Director (Optics), Sira Ltd. Chairman of JPC

B.J. Thompson, Provost, University of Rochester

W.L. Wolfe,

University of Arizona,

Optical Science Center 